\title{
The Anthropological Experiences of Amitav Ghosh in Egypt
}

\author{
A. Ratnam \\ Lecturer in English, B.B.H Degree College, Vetapalem, \\ Prakasam D.T. A.P. India
}

\begin{abstract}
The Imam and the Indian shows different kinds of countries cultures, events, people, riots, and connections between past and present memories that have shared history. The site of violence that sheds communal riots, bloodies and a common historical memory displaces whole populations in the article The Ghosts of Mrs. Gandhi. Yet, it suggests that communal violence can also make visible the connections between and the continuity of social relations and communities that nation seeks to efface. Violence here becomes both sign and testimony of the shared identity of events, memories and communities. It also reveals the frontiers policed by nation states that separate people, communities and also families. He suggests that the nature of boundaries can be understood through the metaphor of the looking glass. The national borders between the people of India and China, Egypt and Tibet share the similar history. Thus, In Ghosh's non-fiction, articles, essays, and short stories the fundamental identity of people, cultures and countries is constructed.

However, I tried to interpret the experiences of Ghosh through this follow period that separated Ghosh's nonfictional novel, The Imamand the Indian signaled the gestation of another project - Ghosh's third book, In an Antique Land that Ghosh was not to embark on until 1989. Outside the world of fiction, as I have seen in this book, Amitav Ghosh is heavily engaged in the political and cultural wars that shape a post-colonial and globalized world. One cannot pretend that The Imam andthe Indian is a unified work, since it consists of essays, articles and short stories written over a couple of decades.
\end{abstract}

Keywords: Cultures, people, Anthropology, superstitions, globalized world

\section{INTRODUCTION}

The non-fiction book "The Imam and the Indian" by Amitav Ghosh was written in Delhi, in 1985, in which Amitav Ghosh conveyed his experiences and his activities with two people, the Imam and Khamees the Rat of the same village. Imam is the man who led the daily prayers in the mosque. He was a leading figure in the village, whom Ghosh wanted to meet and was intrigued by what he had heard about him. People did not often talk about the Imam in the village. Basically, Imam was by profession, a barber anda healer. People said he knew a great deal about herbs and the old kind of medicine. Ghosh has evinced keen interest in knowing more information about Imam. These accomplishments bought the Imam very little credit in the Village. The villagers didn't any longer want the Imam who was also a barber and a healer. Ghosh knew that this was tradition that in rural Egypt, Imam and other religion figures are often by custom associated with those two professions. And no one had time for old-fashioned Imam who made themselves ridiculous by boiling herbs and cutting hair. However, Imam said of many people that the old Imam read a lot. A lot of what? Politics, theology, even popular science.

This made Ghosh all the more to determine to meet Imam. First Ghosh came to the village of the Imam where he found his way to the house of Imam, who lived in the centre of the village, on the dusty open square, which had the mosque in its middle, which was the oldest part of the village. When Ghosh knocked on the door of the Imam, Imam himself opened the door. Ghosh saw that Imam was a big man, with very bright brown eyes, set deep in a wrinkled, weather-beaten face. Imam was distinctly untidy. His blue jallabeyawas mud-stained and unwashed. And his turban had been knotted around his head. But his beard, short and white and neatly trimmed. Age had been crept and harsh on his face, but there was a certain energy in the way he arched his shoulders. It was plain that he was a vigorous, restive kind of person.

Interviewing Ghosh learns that the Imam had divorced his first wife, and his second had left him. Now he lived quite alone, and had his meals with his son's family who lived across the square. 
Moreover, for the next interview, Ghosh met khamees the Rat one morning. His surname is Sudan, as he discovered later. Ghosh liked him at once. Because he was about Ghosh's age, which was in the early twenties, Scrawny, with a thin, mobile face deeply scorched by the sun. He had that brightness of eye and the quick, slightly sardonic turn to his mouth. However, he was completely illiterate. Later Amitav Ghosh learned about Khamees the Rat who was called as the Rat, - because he was said to gnaw away at things with his tongue, like a rat did with its teeth.

Khamees asked so many doubts to Ghosh that burning dead and worshiping cows in India as it in mocking. Then Ghosh replied that it's true that some people in my country burn their dead body, worships cows, as it was a tradition and custom. However, Khamees the Rat asked so many doubts to the author. Meanwhile a woman, who was a dark, aquiline young woman who also asked so many doubts to Ghosh, was Khamees's wife. She asked that tell us doctor, in your country, do you have crops, fields, and canals like those that we do? Yes, he said. However, Ghosh said that we do not always have canals. She also demanded, asked like an innocent that do you have night and day like we do? 'Shut up woman said Khamees of course they do not, its day all the time over there, he also an innocent. Like this, Amitav Ghosh had gone all the way from India to be a student at the University of Alexandria. There he found the innocent, and supersticious people in the Egypt, as it was his fieldwork in the country. He also came across through so many customs and ignorant people. Therefore, these were all the good and bad experiences of Amitav Ghosh in the first title piece of article.

Nabeel's family was one of the poorest in the village. He lived with his parents in a three-room above but along with Aly who is Nabeel's elder brother and Fawzia, the wife of Aly. Moreover, there are three other brothers in his family. Aly worked in the fields for a daily wage. His father carried a tiny salary as a village watchman. He was a small, frail man with sunken cheeks and watery grey eyes. As a watchman, he had the only possession of a gun and an ancient Enfield. Nabeel's mother, a dark, fine-boned woman. There is no one to stand beside Nabeel and his brothers except themselves.

Another important character in this same chapter is Abu-Ali, who was always behaved as though all the worries of the village had fallen on his shoulders. He was always in bed and collapsed on to his bed because he was so fat. In fact, Abu-Ali had been very lucky. He had three sons who had all spent long periods of time in Iraq, they back to Egypt now. So that Abu-Ali could eat two chickens and a pot of rice at one sitting, right after the mid day prayer. There is also an acquaintance in between Abu-Ali and Amitav Ghosh in this article "When I first knew him years ago, he was already so fat that he found near impossible to leave his bed" his neighbors said always, that he ate the way other people force-fed geese, he could eat two chickens and a pot of rice at one sitting. Now that there was Iraqi money in his house.

Thus, in this paper Amitav Ghosh has attempted to describe the structure of social relationships, which constitutes the labour process among a community of Fellahin of the north Western corner of the Nile Delta. However, Amitav Ghosh showed that even though there are important economic differences with in the villagers, but the villagers often say of themselves 'We are all one' and this is at least metaphorically true through this paper. Equally, history plays a critical part in the villagers for estimation of the value of their labour.

Amitav Ghosh also spent a month in Cambodia in early 1993. Then Ghosh was researching an article on an entirely different subject, but inevitably, (Ghosh) spent a great deal of time with UN officials and volunteers. He also conveyed the functioning of the United Nations as UNTAC, and which also the peacekeeping mission in Cambodia. He also conveyed the revolutionary deeds of Khmer Rouge in Cambodia, being a Vietnamese.

What Amitav Ghosh researched was that human history, religion and literature virtually are inseparable, everywhere. Ghosh thought that of non-religious ideologies that have thought of literature as an everywhere.

Amitav Ghosh said in this same article that it is about "Lojja," which is the Bengali novel, which means (shame) by the Bangladeshi writer TaslimaNasrin. Ghosh believed that this book, deeply flawed in many aspects. It is a very crazy novel, which published and became the best seller on both sides of the border. A few months after its publication it has been banned by Bangladesh Government by the demands of religions extremists, and the writer who has been issued a death warrant. Like this 
Ghosh shall try to sketch the chair of events as the history interface fiction. Amitav Ghosh also witnessed for the demolition or before down a 400 Years old mosque in Ayodhya a 6 December 1992. $\mathrm{He}$ also showed the riots broke out and 400 people had died with in the two days. Ghosh quote here a report from Surat, written by a Dutch observer.

Ghosh also conveyed about the great novel called Rajmohun's wife, written by Bankimchandra Chatterjee in the Year 1860 in the same chapter. Bankin was perhaps the first truly 'Indian' writer of modern times. Nirad C. Chaudhuri describes him as 'the creator of Bengali fiction and the greatest novelist in the Bengali language.'such a greatest novelist who mentioned by Ghosh in this chapter.

Amitav Ghosh also conveyed his first novel "The Circle ofReason's" experiences in this same sixteenth article (Journal) in 1983, at the time of the Colombo riots. Soon after wards, Ghosh started the novel The Shadow Lines, which is a second book of him. This book, which had its opening planted in the present, but it, grew downwards into the soil. However, it was in this process that Ghosh examined the ways in which his own life had been affected by civil violence. Ghosh atlast remembered in this book, the stories of his mother had told him about the great Calcutta Killing of 1946.

Amitav Ghosh also conveyed his bad experience with 11 September when he was with his family at house in Brooklyn. In this same Journal on 11 October, a month after the attacks on the World Trade center, the New Yorker organized an evening of readings to raise money for the victims. There Amitav Ghosh was one of those invited to read, then he chose to read two of Shahid's poems. When it was Ghosh's turn to read, he was struck by the sharpness of the contrast between Shahid's voices.BassicallyShahid was a great poet as well as very good novelist. Amitav Ghosh knew him long before Ghosh met him. Shahid's greatest collection was the country without a post office 1997, which had made a powerful mark of impression on Amitav Ghosh.

Another important character in this last chapter was Begum Akhtar, who was a great ghazal singer, whom Shahid had met when he was in his teans. She had become an abiding presence and influenced in his life. There were several shrines - pictures whom Shahid worshipped. Begum Akhtar was one of them along with his father, and mother. 'I loved Begum Akhtar Shahid told Ghosh now and then. In other words, Ghosh could have said that it was a sexual kind of love Shahid said that I could not bear to be away from her. Therefore, his love of Begum Akhtar was such as to powerful sense of identification.

Thus, "Ghat of the only world" is a farewell to the world by Shahid. Amitav Ghosh thus, explores the connections between past and present events and memories, people, cultures and countries that have a shared history in this book The Imam and the Indian. Ghosh also combines his historical and anthropological bent of mind with his skills of a novelist.

Most of the novels of Ghosh; The Imam and the Indian, Dancing in Cambodia, At Large in Burma, Countdown, are the non-fictional narratives. The interest in narration is displayed by characters in all the above fictions and this is reflected particularly in The Glass Palace, but not in The Imam and theIndian. The pleasure in Amitav Ghosh's books lies in the stories, which spin off and then looped back into the loose plot. His narratives follow a line of loosely connected characters, moving like a panoramic picture. In that, he is rightly compared to Salman Rushdie; both of them heirs to a technique of storytelling in which, as The thousand and one nights, the skill lies in ensuring that the story never finishes.

The Imam and the Indian shows different kinds of countries cultures, events, people, riots, and connections between past and present memories that have shared history. The site of violence that sheds communal riots, bloodies and a common historical memory displaces whole populations in the article The Ghosts of Mrs. Gandhi. Yet, it suggests that communal violence can also make visible the connections between and the continuity of social relations and communities that nation seeks to efface. Violence here becomes both sign and testimony of the shared identity of events, memories and communities. It also reveals the frontiers policed by nation states that separate people, communities and also families. He suggests that the nature of boundaries can be understood through the metaphor of the looking glass. The national borders between the people of India and China, Egypt and Tibet share the similar history. Thus, In Ghosh's non-fiction, articles, essays, and short stories the fundamental identity of people, cultures and countries is constructed. 


\section{CONCLUSION}

Thus Ghosh's fiction, the diasporic identity incessantly negotiates between two lands separated by both time and space - history and geography - and attempts to redefine the present through naunced understanding of the past. The narrator in The Imam and the Indian embarks and explores the connections between past and present, events and memories people, cultures and countries that have shared history. Ghosh also combines his historical events with anthropological bent of mind in The Imam and the Indian and in which he makes a journey to discover cultural roots and reasons, with the objective unearthing the buried history.

\section{REFERENCES}

'The Imam and the Indian'. Granta: In Trouble Again. 20 (1986): 135-46. Print.

'The IndianNovel: An Introduction'.Europe -Review LitteraireMensuelle. 79. 864 (2001):36-45. Print.

'The Indian Story: Notes on Some Preliminaries'. Civil Lines New Delhi 1: 35-49.

'The Magic of Reading V.S. Naipaul: An Adolescent Memoir'. EuropeReviewLitteraireMensuelle 80. 873-874 (2002): 293-95. Print.

'The March of the Novel Through History: The Testimony ofmyGrandfather's Bookcase'. Kunapipi 19.3 (1997): 2-13.Reprinted in Kenyon Review. 20. 2 (1998): 13-24.

'Tibetan Dinner'. Granta: Murder. 25 (1988): 250-54. Print.

Tucson, Chan Chao: 'Afterward' in Burma: Something Went Wrong, Nazaraeli P, 2000. Print.

'The World of a Bengali-Speaker in New York'. Observer Magazine London September 1993. Print 